\title{
Organization of Personnel Training in the HR- Management System at Machine-Building Enterprises
}

\author{
Olena Sushchenko ${ }^{1}$, Dariya Basyuk $^{2}$ \\ ${ }^{1}$ Dr. of Sciences (Economics), Professor, S. Kuznets Kharkiv National University of Economics, \\ 61000 Nauky Ave., 9a, Kharkiv, Ukraine \\ ${ }^{2}$ Dr. of Sciences (Economics), Professor, National University of Life and Environmental Sciences of \\ Ukraine, 03041 Heroiv Oborony Str.15, b.3, Kyiv, Ukraine
}

\begin{abstract}
HR management is one of the most important areas of a machine-building enterprise activity. The most important HR management functions are motivation, managing employee relations, training and development, managing employee's quality. The personnel qualitative characteristics are reflected in the degree of professional and qualification suitability for work. Upgrading the skills of the enterprise' personnel and their acquiring of new competencies should be based on lifelong learning system and continuous professional training. Personnel training are important part of the enterprise's HR management system. It contributes to the development of organizational processes, the achievement of the enterprise' goals and objectives. Personnel training aimed at their developing and motivating are a long-term investment in the enterprise employees.
\end{abstract}

\section{Introduction}

Personnel management is one of the key areas in machine building enterprise. Proper employee selection and day-to-day HR management play a major role in the enterprise success. Employee training and development should be concerned, especially in such highentry industry as machine building. Hiring top-level employees takes a lot of time and money and company have no benefit from it. On the other hand, development and implementation of new training programs can benefit company by improving employees' performance, retaining qualified persons and increasing company revenue [1]. In modern work environment, it involves personnel management revision, policies maintenance, fair compensation and benefits administration, foster employees motivation, etc.

\section{HR management modules and functions}

Motivation methodology should be given careful attention as a part of the company's business strategy. Motivational techniques went from using negative patterns such as undervaluing the rewards and "should" coercion to acknowledge pressure employees faced 
with and stress reduction. Indeed, employee's psychological characteristics should be taken into consideration to make these motivation methodic works $[2,3]$.

HR manager should master diverce range of motivation techniques, e.g. employee's perfomance recognition, experience exhchange, career growth plan, fair and benefitial pay, participation in decision-making, private consultations, and many more. To make employee feel important part of the team, their goals and objectives should be monitored. Also manager can make if necessary. Supervision of employee's results make possible to guide them through working process and to hear of what employees really need.

Thus, HR manager can develop mutually beneficial strategy for both employees and company growing demands. Highly qualified experts and their knowledge are what makes machine-building enterprise so profitable and successful $[4,5]$.

The machine-building enterprise personnel, both in numbers and their professional qualification structure, are formed under the influence of technical, technological, organizational, economic, social and demographic factors. Technical and technological factors affecting change through the scope and content of the functions of the labor productivity. The impact of organizational and economic factors is shown in the implementation of such forms and methods of production organizing as mass and specialization, continuity and directness of processes with the shortest duration.

Qualitative and quantitative characteristics of the enterprise personnel are formed under the influence of such factors: number of employees in general and in certain categories; regulated amount of working time; labor intensity level; personnel quality (level of general education and vocational training, physical health); social and physiological factors (labor protection level, occupational disease risk etc.); social and psychological factors (job satisfaction level, the nature of interpersonal relations); socio-economic factors (current system of economic levers and incentives, employee turnover) [6, 7].

For efficient use of personnel and to create conditions for high performance of each employee, the company establishes a technically valid labor standards and revising their, achieves workloads with a relatively lesser number of employees, performs the jobs certification and rationalization, establishes forms of workers organization, carries out ratifications, assigns ranks and categories; sets the working hours and rest time $[8,9]$.

Hence, the qualification level of the personnel determines the competitive enterprise's potential and market dominance. Thus, special functions of personnel management become essential to the machine-building enterprise, where goals must be achieved at the lowest possible cost (Fig. 1).

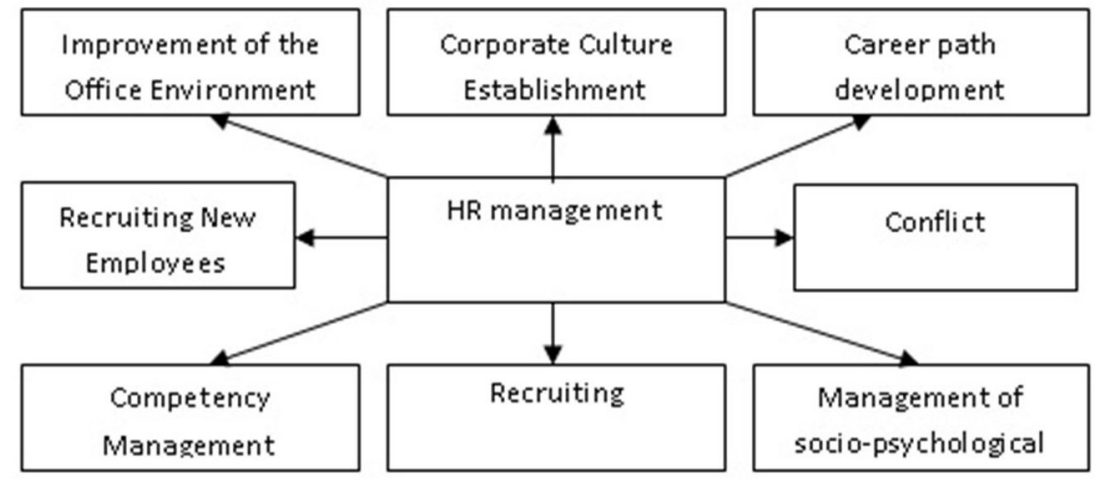

Fig. 1. Special functions of personnel management $[10,11]$.

To make your client happy, your employees should be happy too. Therefore, special functions of personnel management aimed at getting positive feedback from company's management. Employee wants to benefit company's efforts and expects to be treated by 
company in a similar fashion. Such as:

- transparent personnel management system (payroll, discipline);

- fair working conditions (decent working conditions, bonuses, flexible schedule);

- be treated with respect and recognition of employee's achievement;

- establishment of positive socio-psychological climate

- democratic corporate culture;

- career path development;

- professional development opportunities;

- setting clear expectations and responsibilities definition.

The conditions for personnel management system being effective:

- investing in human resources department and special training for new employees to introduce corporate principles and code of conduct,

- arranging training for all employees;

- keeping employees motivated and interested in company success (financial, social and psychological);

- establishment of corporate culture.

HR manager's role is crucial. Let us define the functional requirements for the HR manager (Table 1). We have found that the following list of functions and criteria evaluates the quality of HR management at a machine-building enterprise.

Table 1. HR manager functional requirements.

\begin{tabular}{|l|c|c|}
\hline \multicolumn{1}{|c|}{ Functional requirements (qualification requirements) } & $\begin{array}{c}\text { Management } \\
\text { function }\end{array}$ & $\begin{array}{c}\text { General / } \\
\text { Special }\end{array}$ \\
\hline $\begin{array}{l}\text { Search for new employees; Identify needs and preferred } \\
\text { qualifications; Business plan development in recruiting area }\end{array}$ & Recruiting & Special \\
\hline $\begin{array}{l}\text { Job market study to find possible sources of high-quality job } \\
\text { candidates; Detail research and analysis of company's needs in } \\
\text { new personnel }\end{array}$ & $\begin{array}{c}\text { Personnel's } \\
\text { marketing }\end{array}$ & General \\
\hline $\begin{array}{l}\text { Development and implementation of personnel changes program; } \\
\text { Motivate employees to continue their business career; } \\
\text { Consider new ways to legally protect employees and expanding } \\
\text { their autonomy }\end{array}$ & $\begin{array}{c}\text { Career path } \\
\text { development }\end{array}$ & Special \\
\hline $\begin{array}{l}\text { Providing consultations for top and middle managers in HR area; } \\
\text { Organizing a solid program of training for employees }\end{array}$ & $\begin{array}{c}\text { Competency } \\
\text { Management }\end{array}$ & Special \\
\hline $\begin{array}{l}\text { Evaluation of the employees working activity, their certification; } \\
\text { organizing replacement planning of vacant positions }\end{array}$ & $\begin{array}{c}\text { Evaluation and } \\
\text { analysis }\end{array}$ & Special \\
\hline $\begin{array}{l}\text { Creation of normative and methodological foundation of HR } \\
\text { management; Organization, development and implementation of } \\
\text { measures to improve HR management }\end{array}$ & Organizing & General \\
\hline Implementation of the normative and methodological methods & $\begin{array}{c}\text { All general } \\
\text { functions }\end{array}$ & General \\
\hline $\begin{array}{l}\text { Social development of the team; } \\
\text { Implementation of socio-economic and socio-psychological } \\
\text { management methods; Handling employees concerns }\end{array}$ & $\begin{array}{c}\text { Establishment of } \\
\text { positive socio- } \\
\text { psychological } \\
\text { climate }\end{array}$ & Special \\
\hline $\begin{array}{l}\text { Monitoring compliance with labor law standards; } \\
\text { Control over labor discipline maintenance and internal routine } \\
\text { Creation and maintenance personnel database; } \\
\text { Prsonnel documentation standardization and unification; } \\
\text { vacation schedules }\end{array}$ & $\begin{array}{c}\text { Supervision } \\
\text { registration and } \\
\text { accounting }\end{array}$ & General \\
\hline
\end{tabular}


Therefore, HR department and its functions play a major role in the management of the entire enterprise, it includes both special and basic management functions, and its implementation directly affects the efficiency of the machine-building enterprise.

\section{Personnel training organisation}

The following factors are fundamental for personnel management developing at machinebuilding enterprise:

- build a team able to maintain company's human resources capacity

- create a positive environment for employee

- create a career development and personal development plans for employee

- prevent the employee's dissatisfaction with his or her position to reduce personnel replacement

- regular personnel trainings to improve their skills and competency development.

Personnel training is an organized process, carried out systematically to acquire new knowledge, skills and communication methods under guidance of experienced teachers, mentors, specialists and leaders [12].

It is important to mention efficiency of visual teaching and its advantages over theoretical lectures. To use new knowledge at the full capacity, employee should have a clear picture on study topic and its relevance to company's progress.

Taking into consideration the experience of foreign and domestic researchers, we will give a definition to the basics of personnel's training (Table 2) [13, 14].

Table 2. Personnel's Training Approaches.

\begin{tabular}{|l|l|l|}
\hline \multicolumn{1}{|c|}{ Framework } & \multicolumn{1}{|c|}{ Characteristic } & \multicolumn{1}{c|}{ Impact on employees } \\
\hline Specialized training & $\begin{array}{l}\text { On-The-Job Training for a } \\
\text { current employee' position }\end{array}$ & $\begin{array}{l}\text { Helps employee to be more confident in } \\
\text { his/her area, strengthening self-esteem, but has } \\
\text { short-time effect }\end{array}$ \\
\hline $\begin{array}{l}\text { Multidisciplinary } \\
\text { training }\end{array}$ & $\begin{array}{l}\text { Might include employee's } \\
\text { relocation } \\
\text { departments }\end{array}$ & $\begin{array}{l}\text { Employee can choose the department he/she } \\
\text { best suits for. Thus, less tied to the particular } \\
\text { working place }\end{array}$ \\
\hline $\begin{array}{l}\text { Personality based } \\
\text { training }\end{array}$ & $\begin{array}{l}\text { Targets Human Quality } \\
\text { Development, corporate, } \\
\text { pofessional and life-gained } \\
\text { skills }\end{array}$ & $\begin{array}{l}\text { The most common training for an outstanding } \\
\text { personnel, who is exceptional at research, } \\
\text { teaching or executive roles }\end{array}$ \\
\hline
\end{tabular}

Management of the personnel's training process is one of the HR managers' spheres of action. Organization of study process based on gaining practical experience and studying the sufficient theoretical fundamentals. Thus, study platform useful both for education workers and for managers.

Personnel at machine-building company should be trained according to the high standards of this enterprise (Table 3 ) $[8,12,15]$.

Table 3. Employees' Training Program by Stages.

\begin{tabular}{|c|l|}
\hline Stage & \multicolumn{1}{c|}{ Contents } \\
\hline $\begin{array}{c}\text { Stage One. } \\
\text { Identifying needs }\end{array}$ & $\begin{array}{l}\text { Consulting with heads of the offices, exchange ideas; critical analysis of the } \\
\text { company and market situation; gather employees opinion on the study process; } \\
\text { forecast and plan the expected result of the study process and its consequences }\end{array}$ \\
\hline $\begin{array}{c}\text { Stage Two. } \\
\text { Motivation to Study }\end{array}$ & $\begin{array}{l}\text { The employee should know the purpose of their training; } \\
\text { The employee knows that he/she is obliged to use the knowledge gained in the } \\
\text { study process; } \\
\text { The employee is ready to evaluate the training results; }\end{array}$
\end{tabular}




\begin{tabular}{|c|l|} 
& Study evaluation system is used \\
\hline $\begin{array}{c}\text { Stage Three. } \\
\text { Resource Allocation }\end{array}$ & $\begin{array}{l}\text { Financial assistance ensuring; } \\
\text { Training sessions planning; } \\
\text { Personnel selection }\end{array}$ \\
\hline $\begin{array}{c}\text { Stage Four. } \\
\text { Curriculum } \\
\text { Development }\end{array}$ & $\begin{array}{l}\text { Trainees should match specific requirements to fully harness acquired } \\
\text { knowledge } \\
\text { Choosing an innovative or supportive program }\end{array}$ \\
\hline $\begin{array}{c}\text { Stage Five. } \\
\text { Curriculum } \\
\text { Implementation }\end{array}$ & $\begin{array}{l}\text { Choosing the right training method: venue on- or off-site, individual versus } \\
\text { group learning }\end{array}$ \\
\hline $\begin{array}{c}\text { Stage Six. } \\
\text { Study Process } \\
\text { Efficiency } \\
\text { Measurement }\end{array}$ & $\begin{array}{l}\text { Close the gap between employees current skills and the necessary qualification } \\
\text { Achieving the company's goals and objectives according to the personnel } \\
\text { training method; }\end{array}$ \\
$\begin{aligned} \text { Getting the feedback on did participants enjoy the training or not; } \\
\text { After completing training process, all participants receive test that evaluates }\end{aligned}$ \\
\hline \begin{tabular}{l} 
their knowledge and skills in the work environment \\
\hline
\end{tabular}
\end{tabular}

On-the-job training provided in the form of mentoring from senior colleagues. Beginners are trained by persons who have taken the same way not so long ago. They start to know each other better and used to work together. Thus, the mentoring process based on mutual trust and time consuming.

On-the-job training consists of instructing the student by giving him/her full explanations and demonstration by an experienced employee. Planning and conducting instruction are highly appreciated because of their effectiveness and giving the insight on safety rules. We should mention that training time is short and typically consists of for learning simple operations and activities.

In the machine-building enterprises, coaching methods mostly used in the certain production processes where it is necessary to have problem-solving and quick-thinking mind. Despite being completely practical, coaching methods should be supplemented by soft-skills training (Table 4).

Table 4. Trainings recommended implementing at the machine-building enterprises.

\begin{tabular}{|c|c|c|c|}
\hline Characteristics & \multicolumn{3}{|c|}{ Trainings } \\
\hline Name & Open conversation & $\begin{array}{l}\text { Communication skills } \\
\text { development }\end{array}$ & Cooperation development \\
\hline Goal & $\begin{array}{l}\text { Evaluate your } \\
\text { communication skills, get } \\
\text { feedback from the group, } \\
\text { become better acquainted }\end{array}$ & $\begin{array}{l}\text { Developing effective } \\
\text { communication skills }\end{array}$ & $\begin{array}{l}\text { Practice to approve a } \\
\text { partner, to show him/her } \\
\text { respect and willingness to } \\
\text { cooperate }\end{array}$ \\
\hline Time & 15-20 minutes & $15-20$ minutes & 20-25 minutes \\
\hline Group size & 4-30 persons & Any & 4-30 persons \\
\hline $\begin{array}{l}\text { Enterprise } \\
\text { elements } \\
\text { affected by } \\
\text { training }\end{array}$ & $\begin{array}{l}\text { Publicly visible and } \\
\text { accessible communication } \\
\text { Better image of the } \\
\text { enterprise } \\
\text { Better sales ratio }\end{array}$ & $\begin{array}{l}\text { Publicly visible and } \\
\text { accessible communication } \\
\text { Better image of the } \\
\text { enterprise } \\
\text { Higher quality of the } \\
\text { company's goods and } \\
\text { friendlier support service }\end{array}$ & $\begin{array}{l}\text { Inspiring team work; } \\
\text { Publicly visible and } \\
\text { accessible communication } \\
\text { Better image of the } \\
\text { enterprise } \\
\text { Higher quality of the } \\
\text { company's goods and } \\
\text { friendlier support service }\end{array}$ \\
\hline
\end{tabular}


Most of the biggest industrial enterprises use job rotation technique. Its main function is to have a pool of employees who can be placed at a senior level when someone cannot continue to work at their positions. Job rotation technique shows the employees working style of different positions in the various departments. It is believed that job rotation positively affects employees work efficiency and maintaining the low level of stress. Although, job rotation is expensive to implement and cause an efficiency ratio drop off in time of study. It can also affect the company's innovation [16, 17].

To make study process more flexible, some companies empowers its employees to study on their own. Self-directed learning is based on research of a related documentation, analyzing the data, writing reports, etc. One of the main differences is that employee has less opportunities to practice his/her new skills in mistake-friendly area. Decent HR manager should take control over situation and help the employee to practice his/her skills in order to benefit company and not to harm it. To do so HR manager should think about making a new environment for the employee. Otherwise, employee might not use his/her knowledge at all or use it in less than fruitful way. It is also important to keep employee motivated and to show him/her that their efforts are highly appreciated by seniors.

Study process evaluation allows looking how employees developed their new skills, where study plan should be improved or rewritten completely. It is worth recalling that both employee and employer should get a positive experience and profit from it. Full evaluation of study process can justify increase or decrease of financial support on such training methods. Indeed, finance experts and business analysts should handle this situation with care.

\section{Conclusion}

Personnel training is a crucial element of the management system that contributing to the development of organizational processes and achievement of main goals of the enterprise. To be successful at the world's market, enterprises should have top-tier talents or to raise their own employees to the top-level through continuous study and dedication. As a longterm investment it should be properly calculated by financial and HR teams. Therefore, the evaluation of the effectiveness and results of training should be based on a systematic model of training, starting from setting goals, drawing up training plans and monitoring their implementation. By using innovative solutions in this process and thus building the company's innovation [18].

\section{References}

1. I. Gryshova, M. Petrova, M. Tepavicharova, A. Diachenko, T. Gutsul, Entrepreneurship and Sustainability, 7:1, 690 (2019)

2. M. Petrova, , M. Tepavicharova, L. Dikova, E3S Web of Conferences, 04017 IIIrd International Innovative Mining Symposium (2018)

3. Korostelev V., Labor market, 296 (1991)

4. M. Petrova, I. Buzko, Yu. Dyachenko, 17th International Scientific Conference ERDev (2018)

5. R. Pukala, M. Petrova, IVth International Innovative Mining Symposium E3S Web of Conferences (2019)

6. I. Buzko, E. Sushchenko, , Socialno-ekonomicheskie aspekty promyshlennoj politiki socialno-trudovye otnosheniya v sovremennyx ekonomicheskix usloviyax, 1, 68 (2001)

7. N. Kurmanov, M. Petrova, S. Suleimenova, IV ${ }^{\text {th }}$ International Innovative Mining Symposium E3S Web of Conferences (2019) 
8. T. Uteubayev T., Petrova M., I. Lyubenova, Innovations in science and education Book Series: CBU International Conference Proceedings Pages, 491 (2018)

9. N. Kurmanov, B. Tolysbayev, D. Aibossynova, N. Parmanov, Economic Annals-XXI, 158:3-4, 57 (2016)

10. E. Maslov, Human Resources Management (2009)

11. O. Krushelnytska, Personnel Management (2006)

12. E. Bezlepkyna, Modern methods of staff training (2010)

13. N. Nenkov, Y. Dyachenko, M. Petrova, G. Bondarenko, V. Pustovit, "European Journal of Sustainable Development", 6:4, (2017)

14. T. Komissarova, Human Resources Management. 316 (2002)

15. O. Sushchenko, I. Trunina, D. Zagirniak, 2017 IEEE International Conference on Modern Electrical and Energy System (MEES), 344 (2017)

16. R. Pukala, Engineering Management in Production and Services, 8:3, 43 (2016)

17. T. Odinokova,. Ecology. Socium, 3:2, 1 (2019)

18. R. Pukala, IVth International Innovative Mining Symposium E3S Web of Conferences (2019) 